\title{
Correlation between Serum Vitamin D levels and hypertensive disorders in pregnancy in primigravida in third trimester
}

\author{
Rao A. ${ }^{1}$, Ghose S. ${ }^{2}$, Rathod S. ${ }^{3}$ \\ ${ }^{1}$ Dr. Ashwin Rao, Postgraduate, ${ }^{2}$ Dr. Seetesh Ghose, Professor and Head, ${ }^{3}$ Dr. Setu Rathod, Associate Professor; all authors \\ are affiliated with Department of Obstetrics and Gynecology, Mahatma Gandhi Medical College and Research Institute, \\ Puducherry, India.
}

Corresponding Author: Dr. Ashwin Rao, Postgraduate, Department of Obstetrics and Gynecology, Mahatma Gandhi Medical College and Research Institute, Puducherry, India. Email: ashwinrao2404@gmail.com

\begin{abstract}
Background: Hypertension related to pregnancy is a common obstetric complication observed in $7-8 \%$ of the antenatal cases in India. Vitamin D is involved in the development of the placenta and feto-maternal wellbeing, thereby helping in prevention of obstetric complication like hypertension in pregnancy. It modulates various biochemical reactions in the body to prevent abnormal placentation preventing pregnancy related hypertension. Materials and methods: A cross sectional observational study was conducted on 120 antenatal women between April 2017 - March 2018 in Mahatma Gandhi Medical College and Research Institute. Based on blood pressure, primigravidas were classified as Mild (Group 1) and Severe (Group 2). Investigations for hypertensive disorders of pregnancy and serum Vitamin D were done. Serum Vitamin D levels were classified into deficiency, insufficiency $(20-30 \mathrm{ng} / \mathrm{ml})$ and sufficiency $(30-100 \mathrm{ng} / \mathrm{ml})$. Statistical analysis was done using SPSS-17. Results: In this study, among the primigravidas with hypertensive disorders of pregnancy $67.5 \%$ were Vitamin D deficient, 24.2\% had insufficiency and $8.3 \%$ had sufficient serum Vitamin D levels. It was also observed that the serum Vitamin D levels were significantly low with an increase in the pre-pregnancy BMI (P value - 0.002) and increase in blood pressure ( $\mathrm{P}$ value - 0.004). There was significant negative correlation seen between serum vitamin $\mathrm{D}$ and blood pressure as we moved from the mild to the severe hypertension group. Conclusion: With lower levels of serum vitamin D, more was the severity of hypertension in pregnancy. Obesity was also associated with severe vitamin D deficiency in the present study.
\end{abstract}

Keywords: Hypertensive disorders of pregnancy, Obesity, Exposure to sunlight, Vitamin D

\section{Introduction}

Vitamin D is a precursor for several biochemical reactions in the body and mainly involved in calcium-phosphorus metabolism and mineralisation of the bones. Vitamin D unlike other vitamins does not require daily supplementation; sunlight exposure replenishes the body stores. It is commonly observed when people are subjected to inadequate sunlight exposure, poor dietary habits, bedridden individuals and extremes of age.

Vitamin D is also involved in the development of the placenta and feto-maternal wellbeing, thereby helping in prevention of obstetric complication like hypertension in pregnancy[1]. Hypertension in pregnancy is a common obstetric complication leading to signs like thrombo cytopenia, elevated liver enzyme, haemolysis, seizures and bleeding manifestations which account for the high maternal morbidity and mortality. There have been

Manuscript received: $8^{\text {th }}$ June 2018

Reviewed: $18^{\text {th }}$ June 2018

Author Corrected: $26^{\text {th }}$ June 2018

Accepted for Publication: $30^{\text {th }}$ June 2018

Obsgyne Review: Journal of Obstetrics and Gynecology several studies done to find an association between hypertension related to pregnancy and levels of calciferol in the body. Observations made by Bodnar LM et al and Burris et al have suggested that low calciferol levels have associated with an increased chance of developing gestational diabetes, preterm births and preeclampsia [2,3]. Merewood A et al found association of Vitamin D deficiency with increased rates of caesarean section[4].

Bener A et al studied that hypovitaminosis D was associated with 5 times higher chance of developing hypertension during pregnancy [5].The risk of the mothers giving birth to neonates which were small for gestation age was also much higher when they had suboptimal Vitamin D levels [6]. Vitamin D has a regulatory action on centrally acting vasodilating agents and has been found to regulate blood pressure. Vitamin D has also been found to modulate various immunological agents and suppress autoimmune antibodies so as to prevent abnormal placentation thereby preventing hypertension related to Available online at: www.medresearch.in 21 | P a g e 
pregnancy [7]. But on the contrary Anupama Dave et al (2016) felt that there was no causal relationship between low vitamin D level and adverse maternal and neonatal outcome in terms of hypertension, anaemia, caesarean section rates, diabetes or bony pain[8]. Hence an effort was made to establish the relationship between serum level of vitamin D in hypertensive disorders in pregnancy and if a correlation exists between the serum level of vitamin $\mathrm{D}$ and the severity of hypertensive disorder in pregnancy.

\section{Aims}

To find the correlation of serum Vitamin D levels with hypertensive disorder in pregnancy.

\section{Objectives}

1. To estimate the serum Vitamin D levels in primigravida with gestational age $28-40$ weeks with hypertensive disorders of pregnancy.

2. To find a correlation between serum Vitamin D levels and severity of hypertensive disorders of pregnancy.

\section{Materials and Methods}

Place of study: Dept. of Obstetrics and Gynecology, Mahatma Gandhi medical college and research institute, Puducherry.

Type of study: Cross sectional observation study

Sampling methods: Consecutive sample

\section{Inclusion criteria}

$>$ Primigravida with gestational age between 28-40 weeks.

$>$ Maternal age 19-35 years of age

$>$ Patients diagnosed to have hypertensive disorder in pregnancy

\section{Results}

This observational comparative study was conducted in the Department of obstetrics and gynaecology, Mahatma Gandhi Medical College and Research Institute, Puducherry. The demographic characteristics are described in Table.1. The total number of participants in the study were $n=120$. Among the participants, $67.5 \%$ had vitamin D deficiency, 24.2\% had Vitamin D insufficiency and $8.3 \%$ had Vitamin D sufficiency. It was observed that $75 \%$ of the studied population had mild hypertension and 25\% had severe hypertension based on ACOG 2014 guidelines. In the population studied, 67.5\% had Vitamin D deficiency irrespective to the age, exposure to sunlight and first trimester BMI.

Age and exposure to sunlight did not bear any significance to the levels of serum Vitamin D. On comparing the mean serum Vitamin D levels in the three BMI groups, the obese group had significantly lower mean serum vitamin D levels when compared to the over weight and normal groups. On comparing the mean serum Vitamin D levels in the two blood pressure groups, the blood pressure group 2 has significantly lower mean serum vitamin D levels when compared to group 1. (Table.2) Overall, there was a significant negative correlation between serum Vitamin D levels with systolic blood pressure ( $\mathrm{p}$ value$0.015)$, diastolic blood pressure $(P$ value- 0.005$)$ and mean arterial pressure ( $p$ value -0.006$)$ respectively which was statistically significant $(\mathrm{p}$ value $=0.015$ ). This implies that with an increase in systolic, diastolic and mean arterial blood pressure levels among primigravida in the third trimester with hypertensive disorders of pregnancy, there is significant reduction in serum Vitamin D levels. (Table.3) In Group 1, there was a significant negative correlation between serum 
Original Research Article

Vitamin D levels with systolic blood pressure (P value- 0.032) but not with diastolic blood pressure and mean arterial pressure respectively. In Group 2, there was a significant negative correlation between serum Vitamin D levels with systolic $(P$ value -0.007$)$ and diastolic blood pressure ( $p$ value- 0.002 ) respectively but not with mean arterial pressure. Fig. 1 scatter plot shows a 5\% variability in the Vitamin D levels, explained by the linear relationship between systolic blood pressure and Vitamin D. It is seen that $6 \%$ of the variability in the Vitamin D levels is explained by the linear relationship between diastolic blood pressure and Vitamin D. (Fig. 2) It is seen that $6 \%$ of the variability in the Vitamin D levels is explained by the linear relationship between mean arterial blood pressure and Vitamin D (Fig.3)

Table-1: Distribution of all variables: $(n=120)$

\begin{tabular}{|c|c|}
\hline Maternal factors & Characteristics \\
\hline Age in years - Mean $( \pm$ SD $)$ & $24.9( \pm 3.5)$ years \\
\hline \multicolumn{2}{|l|}{ Exposure to sunlight } \\
\hline Outdoor workers & $14(11.7 \%)$ \\
\hline Indoor workers & $106(88.3 \%)$ \\
\hline BMI- Mean $( \pm \mathrm{SD})$ in $\mathrm{kg} / \mathrm{m}^{2}$ & $29.82( \pm 5.75)$ \\
\hline \multicolumn{2}{|l|}{ BMI- n, (\%) } \\
\hline Normal & $25(20.8 \%)$ \\
\hline Overweight & $51(42.5 \%)$ \\
\hline Obese & $44(36.7 \%)$ \\
\hline POG in weeks - Median(range) & $38(28-40)$ weeks \\
\hline Blood Pressure Factors & Characteristics \\
\hline Systolic in mm of Hg- Mean(+/- SD) & $149.1( \pm 10.6) \mathrm{mm}$ of $\mathrm{Hg}$ \\
\hline Diastolic in $\mathrm{mm}$ of $\mathrm{Hg}-\mathrm{Mean}(+/-\mathrm{SD})$ & $95.3( \pm 6.7) \mathrm{mm}$ of $\mathrm{Hg}$ \\
\hline $\begin{array}{l}\text { Mean arterial pressure (MAP) in } \mathrm{mm} \text { of } \mathrm{Hg}-\text { Mean } \\
\qquad(+/-\mathrm{SD})\end{array}$ & $113.2( \pm 7.5) \mathrm{mm}$ of $\mathrm{Hg}$ \\
\hline \multicolumn{2}{|l|}{ Blood Pressure group- n, (\%) } \\
\hline Group $1^{*}$ & $90(75 \%)$ \\
\hline Group $2^{* *}$ & $30(25 \%)$ \\
\hline
\end{tabular}

*Group 1 - MILD HYPERTENSION - BP - 140/90 - 159/109 mm of Hg

**Group 2 - SEVERE HYPERTENSION - BP - $\geq 160 / 110 \mathrm{~mm}$ of Hg

Table-2: Distribution of Serum Vitamin D groups among the other variable groups.

\begin{tabular}{|c|c|c|c|c|c|}
\hline Variable Groups & $\mathbf{N}(\%)$ & $\begin{array}{c}\text { Vitamin D } \\
\text { Deficient } \\
\text { N(\%) }\end{array}$ & $\begin{array}{c}\text { Vitamin D } \\
\text { Insufficiency } \\
\quad \mathbf{N}(\%)\end{array}$ & $\begin{array}{l}\text { Vitamin D } \\
\text { Sufficiency } \\
\text { N(\%) }\end{array}$ & $\begin{array}{c}P \\
\text { Value }\end{array}$ \\
\hline $\begin{array}{l}\text { Age group } \\
<30 \text { years } \\
\geq 30 \text { years }\end{array}$ & $\begin{array}{c}107 \\
13\end{array}$ & $\begin{array}{l}72(67.3 \%) \\
11(84.6 \%)\end{array}$ & $\begin{array}{c}28(26.2 \%) \\
1(7.7 \%)\end{array}$ & $\begin{array}{l}7(6.5 \%) \\
1(7.7 \%)\end{array}$ & 0.152 \\
\hline \begin{tabular}{|c|} 
Exposure to sunlight \\
Outdoor workers (More exposure) \\
Indoor workers (Less exposure) \\
\end{tabular} & $\begin{array}{c}14 \\
106 \\
\end{array}$ & $\begin{array}{c}8(57.1 \%) \\
75(70.8 \%)\end{array}$ & $\begin{array}{c}4(28.6 \%) \\
25(23.6 \%)\end{array}$ & $\begin{array}{c}2(14.3 \%) \\
6(5.7 \%)\end{array}$ & 0.513 \\
\hline $\begin{array}{l}\text { BMI group } \\
\text { Normal } \\
\text { Overweight } \\
\text { Obese }\end{array}$ & $\begin{array}{l}25 \\
51 \\
44\end{array}$ & $\begin{array}{c}16(64 \%) \\
34(66.67 \%) \\
33(75 \%)\end{array}$ & $\begin{array}{c}7(28 \%) \\
13(25.5 \%) \\
9(20.5 \%)\end{array}$ & $\begin{array}{l}2(8 \%) \\
4(7.8 \%) \\
2(0.5 \%)\end{array}$ & 0.002 \\
\hline $\begin{array}{c}\text { Blood pressure group } \\
\text { Group } 1 \text { (Mild) } \\
\text { Group } 2 \text { (Severe) }\end{array}$ & $\begin{array}{l}90 \\
30\end{array}$ & $\begin{array}{l}57(63.3 \%) \\
26(86.7 \%)\end{array}$ & $\begin{array}{c}25(27.8 \%) \\
4(13.3 \%)\end{array}$ & $\begin{array}{c}8(8.9 \%) \\
0(0 \%)\end{array}$ & 0.004 \\
\hline Total & 120 & $62(62 \%)$ & $31(31 \%)$ & $7(7 \%)$ & \\
\hline
\end{tabular}

*the mean difference is significant at 0.05 
Original Research Article

Table-3: Correlations between systolic and diastolic blood pressure and serum Vitamin D levels.

\begin{tabular}{|c|c|c|c|}
\hline Blood pressure & $\begin{array}{c}\text { Vitamin D levels in Group 1 } \\
\text { (Mild hypertension) }\end{array}$ & $\begin{array}{c}\text { Vitamin D levels in Group 2 } \\
\text { (Severe hypertension) }\end{array}$ & $\begin{array}{c}\text { Vitamin D } \\
\text { (Overall) }\end{array}$ \\
\hline Systolic - r(p value) & $-0.163(0.032)$ & $-0.328(0.007)$ & $-0.223(0.015)$ \\
\hline Diastolic - r(p value) & $0.013(0.910)$ & $-0.363(0.002)$ & $-0.252(0.005)$ \\
\hline $\begin{array}{c}\text { Mean arterial } \\
\text { pressure }\end{array}$ & $-0.129(0.227)$ & $0.044(0.819)$ & $-0.248(0.006)$ \\
\hline
\end{tabular}

' $r$ ' is the Pearson's correlation coefficient. *the mean difference is significant at 0.05

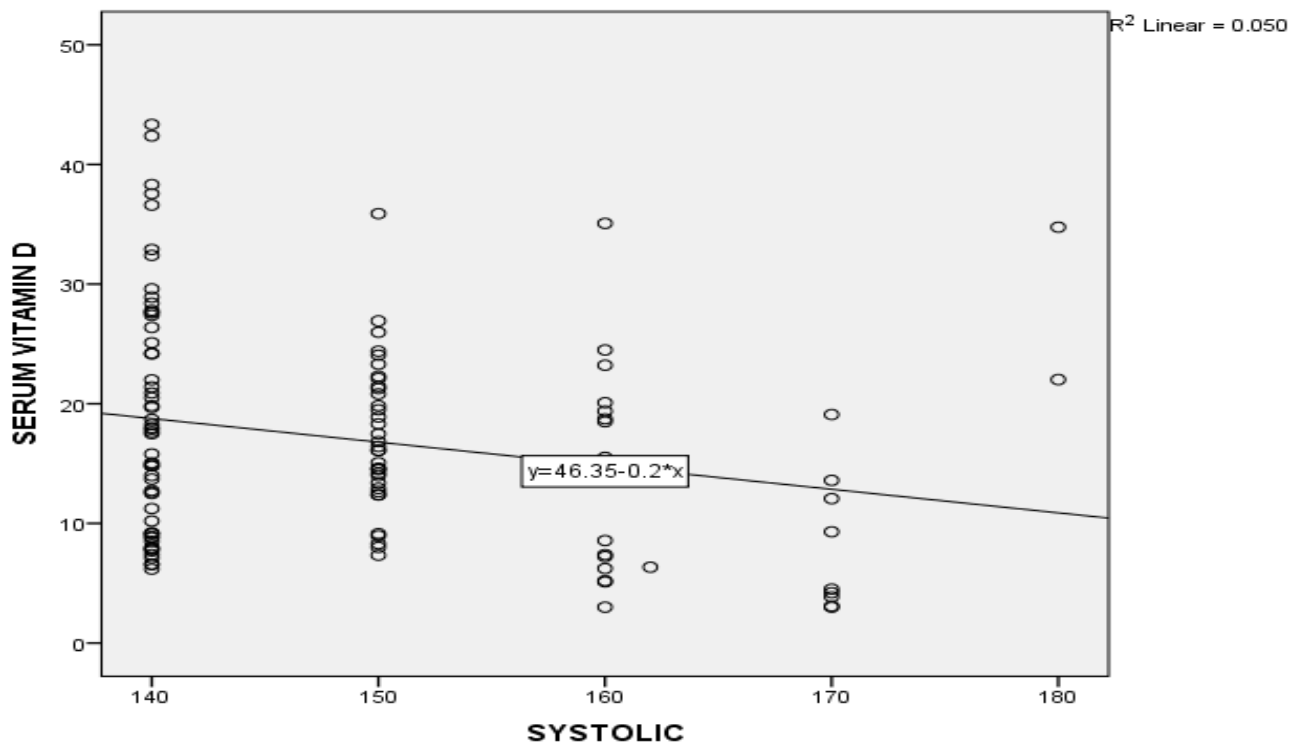

Fig-1: Scatter plot shows the linear relationship between systolic blood pressure and serum Vitamin D levels. $N=120$

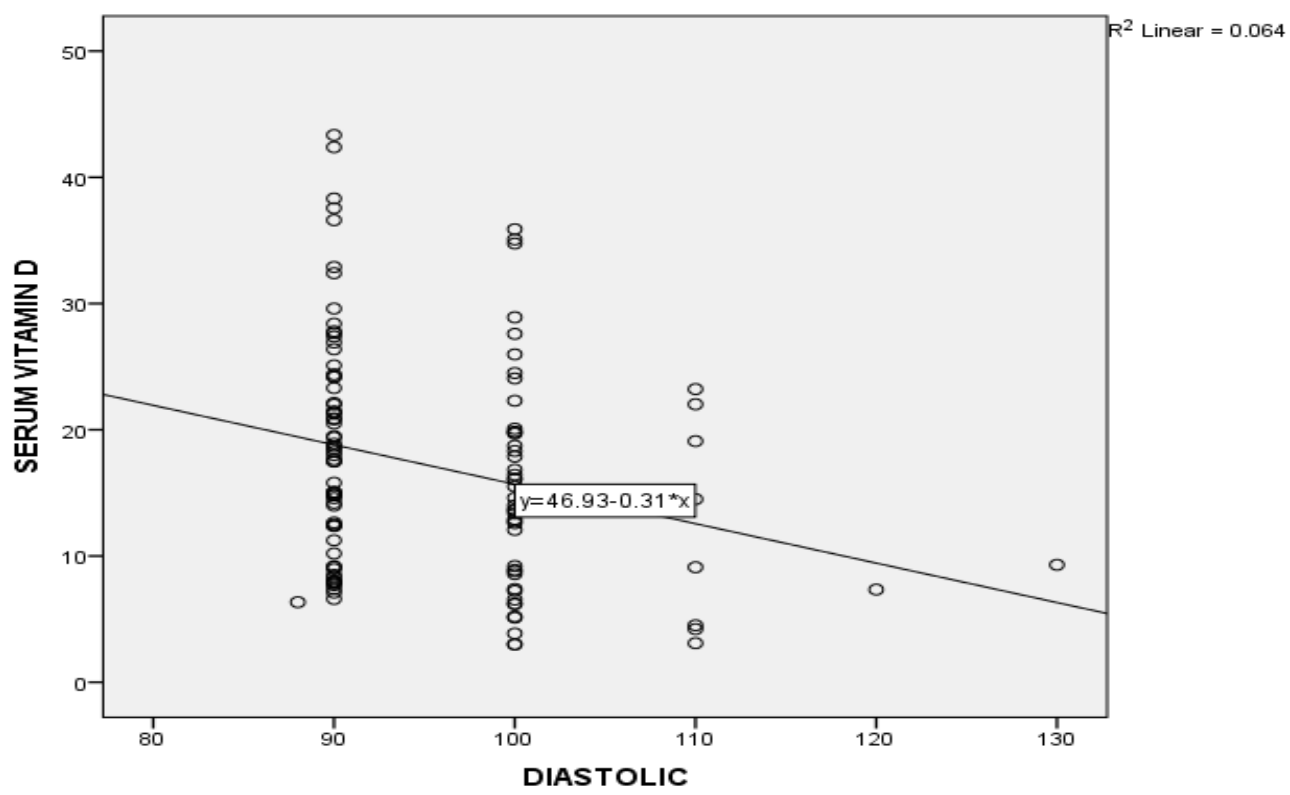

Fig-2: Scatter plot shows the linear relationship between diastolic blood pressure and serum Vitamin D levels. $N=120$ 


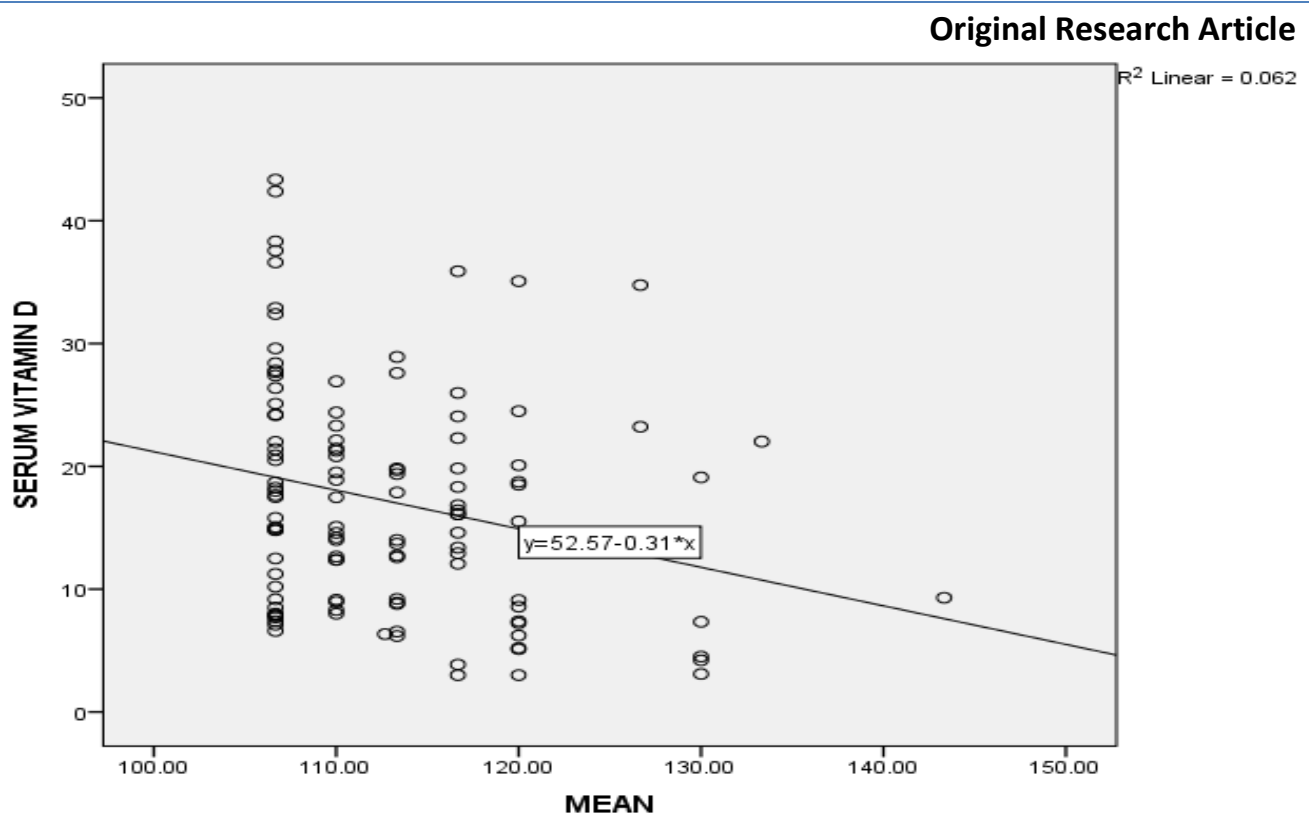

Fig-3: Scatter plot shows the linear relationship between mean arterial blood pressure and serum Vitamin $D$ levels. $N=120$

\section{Discussion}

The present study was undertaken to establish an association between Vitamin D levels and hypertension in pregnancy in primigravidas between 28 - 40 weeks admitted to Mahatma Gandhi Medical College and Research Institute between April 2017 and Mar 2018. 120 cases who were admitted from the obstetrics and gynaecology OPD with high blood pressures were taken and Vitamin D levels were assessed.

In the present study, it was observed that majority of the subjects had suboptimal levels of serum Vitamin D. Almost $92 \%$ of the patients recruited had Vitamin D levels less than $30 \mathrm{ng} / \mathrm{ml}$. In northern India, Jain V et al (2011)[9], Goel P et al (2016)[10], Agarwal S et al (2016) [11] and Kumari et al (2017)[12] observed that the serum levels of Vitamin D of most of their subjects had low values of vitamin D during the last few weeks of gestation. (Table 4) The mean age observed among the cases was $24.9 \pm 3.5$ years and Vitamin D deficiency was more when the age was greater than and equal to 30 years (84.6\%) when compared the population less than 30 years (65.4\%). Goel P et al (2016) observed that the mean age among women with hypertensive disorders of pregnancy was 25.48 years and that $83.3 \%$ of those subjects were Vitamin D deficient[10] Dave A et al (2017) observed that pregnant women below 30 years of age had higher odds of developing deficiency of Vitamin D compared to the older population[8]. The sunlight exposure was also considered based on the whether the woman's occupation involved outdoor (more exposure) or indoor (less exposure) work. The number of cases with vitamin D deficiency was compared. In the present study, 88.33\% had less exposure to sunlight which suggests that a majority of our patients were involved with indoor work whereas only $11.67 \%$ had more exposure. Bener et al observed that $36.6 \%$ had more exposure and 63.4\% had less exposure [13]. In India, Dave A et al (2016) and Kumari et al (2017) et al observed that $38.1 \%$ and $35 \%$ had good exposure to sunlight and $61.9 \%$ and $65 \%$ had less exposure respectively[8,12].

Table-4: Table showing the distribution of serum Vitamin D levels in the patients in our study when compared to others.

\begin{tabular}{|c|c|c|c|c|c|}
\hline & $\begin{array}{c}\text { Jain V } \\
\text { et al (2011) }\end{array}$ & $\begin{array}{c}\text { Goel P } \\
\text { et al (2016) }\end{array}$ & $\begin{array}{c}\text { Agarwal S et al } \\
\mathbf{( 2 0 1 6 )}\end{array}$ & $\begin{array}{c}\text { Kumari } \\
\text { et al (2017) }\end{array}$ & $\begin{array}{c}\text { Our } \\
\text { study }\end{array}$ \\
\hline $\begin{array}{c}\text { Vitamin D } \\
\text { deficiency }\end{array}$ & $81.1 \%$ & $92 \%$ & $83.4 \%$ & $77.09 \%$ & $67.5 \%$ \\
\hline $\begin{array}{c}\text { Vitamin D } \\
\text { insufficiency }\end{array}$ & $11.6 \%$ & $6 \%$ & $11.1 \%$ & $22.91 \%$ & $24.2 \%$ \\
\hline $\begin{array}{c}\text { Vitamin D } \\
\text { sufficiency }\end{array}$ & $7.3 \%$ & $2 \%$ & $5.53 \%$ & & $8.3 \%$ \\
\hline
\end{tabular}




\section{Original Research Article}

In the present study, on the basis of BMI, 36.67\% were obese. It was seen that among the obese subjects, $72.7 \%$ and $20.45 \%$ were Vitamin D deficient and insufficient respectively which was significant ( $p$ value - 0.002). Hence an inverse relationship between Vitamin D and BMI was observed which could have been due to the fact that higher levels of body fat hampered vitamin D absorption. It was also seen that the finding from our study was in congruence with several other studies as described. Bodnar et al (2007) also described that among the cases studied, there was an increased rate of subnormal levels of Vitamin D among the obese subjects ( $p$ value $<0.05$ ) [14]. Zad ND et al (2014) observed that 38\% of their subjects fell under the obese category and that there was a moderate negative correlation $(p<0.001)$ between BMI and serum levels of Vitamin $\mathrm{D}$ during the first trimester [15]. Agarwal S et al (2016) observed in their study that among the obese cases, $100 \%$ were Vitamin D deficient[11]. Pena HR et al (2015) observed that among the obese subjects with normal blood pressure, 32.5\% were Vitamin D deficient and $47.5 \%$ had insufficient Vitamin D levels. But when along with obesity, preeclampsia was also considered, then $47.7 \%$ were Vitamin D deficient, 47.7\% had Vitamin D insufficient (P value -0.002)[16]. This showed that obesity by itself was an independent risk factor for Vitamin D deficiency but when obese individuals had associated preeclampsia, the risk only worsened.

In the present study, we found that the mean systolic blood pressure was $149.1( \pm 10.6) \mathrm{mm}$ of $\mathrm{Hg}$ and the mean diastolic blood pressure was $95.3( \pm 6.7) \mathrm{mm}$ of $\mathrm{Hg}$. Among the group 1 subjects (mild hypertension), we found that $91 \%$ had suboptimal Vitamin D levels, whereas in group 2 (severe hypertension) $100 \%$ of the subjects had suboptimal serum Vitamin $\mathrm{D}$ levels ( $\mathrm{P}$ value $<0.001$ ). The initial research studied the likelihood of development of preeclampsia on the basis of exposure to sunlight as it varies every season. It was proposed that the amount of exposure to sunlight was directly proportional to the Vitamin D produced in the body. Magnus et al (2001) suggested that the chances of developing preeclampsia was more during the winter months like December compared to the summer due to lesser exposure to sunlight during the winter[17].

Whereas Algert et al (2010) had a different concept as he felt that the amount of sunlight exposure mattered more around the time of delivery which decreased the odds of developing preeclampsia and not around conception. Algert et al also felt that the prevalence of preeclampsia was less in less among those who conceived in autumn compared to spring[18]. The studies conducted later emphasised more on the circulating serum levels of Vitamin D in the body along with sunlight exposure to include the groups who were at risk of developing Vitamin D deficiency. Bodnar et al (2007 and 2014), Aghajafari et al (2009), Robinson et al (2010), Bener et al (2013) and Hyppönen et al (2014) studied the relationship between serum Vitamin D levels and various maternal outcomes comparing similar parameters in different parts of the world. They all arrived at similar conclusions wherein they observed that suboptimal Vitamin D in mothers can lead to gestational diabetes mellitus, various forms of hypertensive disorders of pregnancy and pregnancy induced anaemia[19,2,20,21,5,6]. Aghajafari et al (2009) and Gernand et al (2014) studied the neonatal outcomes along with the maternal complications and concluded that maternal Vitamin D deficiency had a higher risk of preterm infants and babies which were small for the gestational age (SGA)[20,6]. Robinson et al (2010) and Bodnar et al (2014) noted that their cases with severe preeclampsia were associated with extremely low levels of vitamin D.

The former observed that 54\% and 22\% was Vitamin D deficient and insufficient respectively ( $\mathrm{p}$ value - 0.005); they also observed that a $10 \mathrm{ng} / \mathrm{mL}$ increase in Vitamin D was associated with a 63\% less chance of developing preeclampsia [21]. Whereas the latter observed that when patients attained Vitamin D of more than $50 \mathrm{nmol} / \mathrm{L}$, there was a $40 \%$ less chance in developing severe preeclampsia [2]. Bakacek Murat et al (2015) studied the Vitamin D with respect to the severity of hypertensive disorders of pregnancy but obtained no significant difference between the mild and the severe forms although there were statistically significant findings when compared to the controls [23]. When compared to our study, similar findings were reported by Kumari et al (2017) in northern India such that in cases with mild and severe preeclampsia, 95\% and 100\% had suboptimal Vitamin D levels respectively with a combined $\mathrm{p}$ value of $<0.05$. They also found a negative correlation between Vitamin D at term and blood pressure with a significant P value[12]. But contrary to all the above mentioned studies, Dave A et al in a study conducted in northern India concluded that their study showed no causal relationship between suboptimal Vitamin D levels and maternal or neonatal complications [8].

\section{Conclusion}

Based on our results, it can be concluded that there is a significant negative correlation between the serum vitamin D levels and hypertensive disorders in pregnancy. The lower the serum vitamin D levels, more is the severity of hypertension in pregnancy. It was also observed that obesity is associated with severe vitamin D deficiency which is evident from the drop in serum vitamin D levels as we move from the normal to the obese BMI group. Hence there is a need for supplementation of calciferol during pregnancy in order to reduce the risk of 
serious maternal or neonatal outcome. Proper guidelines which can recommend the apt dosage of supplementation when vitamin D deficiency is diagnosed at different periods of gestation is required.

\section{Author contributions:}

Dr.Ashwin Rao is the principal investigator who conducted the study.

Dr. Seetesh Ghose guided the principal investigator during the process of the study.

Dr. Setu Rathod helped the principal investigator in the process of the study and manuscript preparation.

We are grateful to all the patients for their cooperation during the study process.

Scope for knowledge: Vitamin D deficiency is a predisposing factor for hypertensive disorders of pregnancy, gestational diabetes mellitus, preterm births and various adverse obstetric outcomes. We were able to correlate the grade of Vitamin D deficiency with the severity of hypertensive disorders of pregnancy. This study also opens the scope for other studies to come up with guidelines for proper supplementation of Vitamin D right from the preconceptional period to prevent adverse obstetric outcomes.

\section{Funding: Nil, Conflict of interest: Nil Permission from IRB: Yes}

\section{References}

1. Ota K, Dambaeva S, Kim MW, Han AR, Fukui A, Gilman-Sachs A, Beaman K, Kwak-Kim J. 1, 25Dihydroxy-vitamin D3 regulates NK-cell cytotoxicity, cytokine secretion, and degranulation in women with recurrent pregnancy losses. Eur J Immunol. 2015 Nov; 45 (11):3188-99.doi:10.1002/eji.201545541.Epub 2015Sep7.

2. Bodnar LM, Simhan HN, Catov JM, Roberts JM, Platt RW, Diesel JC, Klebanoff MA. Maternal vitamin D status and the risk of mild and severe preeclampsia. Epidemiology. 2014Mar;25(2):207-14.doi: 10.1097/ EDE. 0000000000000039

3. Burris HH, Camargo CA. Vitamin D and gestational diabetes mellitus. Curr Diab Rep. 2014 Jan; 14 (1):451. doi: 10.1007/s11892-013-0451-3.

4. Merewood A, Mehta SD, Chen TC, Bauchner H, Holick MF. Association between vitamin D deficiency and primary cesarean section. Merewood A, Mehta SD, Chen TC, Bauchner H, Holick MF. Association between vitamin D deficiency and primary cesarean section. J Clin Endocrinol Metab. 2009 Mar; 94 (3):940-5.doi: 10. 1210 /jc. 2008-1217.

Obsgyne Review: Journal of Obstetrics and Gynecology

\section{Original Research Article}

5. Bener A, Al-Hamaq AO, Saleh NM. Association between vitamin D insufficiency and adverse pregnancy outcome: global comparisons. Int J Womens Health. 2013; 5:523-31.doi: 10.2147/IJWH.S51403.

6. Gernand AD, Simhan HN, Caritis S, Bodnar LM. Maternal vitamin D status and small-for-gestational-age offspring in women at high risk for preeclampsia. Obstet Gynecol. 2014 Jan; 123(1):40-8. doi: 10.1097/AOG. 000 0000000000049 .

7. Chan SY, Susarla R, Canovas D, Vasilopoulou E, Ohizua O, Mc Cabe CJ, et al. Vitamin D promotes human extravillous trophoblast invasion in vitro. Placenta. 2015 Apr; 36 (4):403-9. doi: 10.1016/j. placenta. 2014. 12.021. Epub 2015 Jan 8.

8. Dave A, Verma M, Jain N, Dave A. A study of vitamin D levels and associated deficiency in pregnancy and its effect on maternal and fetal outcome. Int $\mathrm{J}$ Reprod Contracept Obstet Gynecol. 2016 Dec 20;6:84-8.doi: 10. 18203/2320-1770.ijrcog20164637.

9. Jain V, Gupta N, Kalaivani M, Jain A, Sinha A, Agarwal R. Vitamin D deficiency in healthy breastfed term infants at 3 months \& their mothers in India: Seasonal variation \& determinants. Indian J Med Res [serial online ]2011[cited 2018 Jul 18];133:267-73. Available from: http://www.ijmr.org.in/text.asp?2011/ $133 / 3 / 267 / 78334$

10. Goel P, Garg G, Kaur J, Mehra R, Tandon R, Huria A. Association of vitamin D deficiency during pregnancy with preeclampsia and eclampsia. Int J Reprod Contracept Obstet Gyneco 12016;5:3046-50.doi: http://dx.doi.org/10. 18203/2320-1770.ijrcog20162982

11. Agarwal S, Chaudhary M, Chauhan J, Vacchani A. Assessment of Vitamin D Deficiency in Pregnant Females Attending Antenatal Care Clinic at Tertiary Care Hospital. Int J Sci Stud 2016; 4 (5):99-101. doi: 10.17354/ijss/ 2016/437.

12. Kumari A, Mitra S, Tiwari HC, Srivastav R. Hypovitaminosis D in pregnancy and its correlation with preeclampsia and gestational diabetes mellitus. Int $\mathrm{J}$ Reprod Contracept Obstet Gynecol 2017; 6:890-6.doi: http: // dx. doi.org/10. 18203/2320-1770. Ijrcog 20170 551.

13. Bener A, Al-Ali M, Hoffmann GF. High prevalence of vitamin $\mathrm{D}$ deficiency in young children in a highly sunny humid country: A global health problem. Minerva Pediatr. 2009; 61: 15-22.doi: 10.4103/1817-1745.147574.

Available online at: www.medresearch.in 27 | P a g e 
14. Bodnar LM, Catov JM, Roberts JM, Simhan HN. Prepregnancy obesity predicts poor vitamin D status in mothers and their neonates,.J Nutr. 2007 Nov; 137 (11): 2437-42.

15. Zad ND, Vaezi M, Esmaeli H, Khalatbari S, Hamedani M. PO-0619 Association Between Prepregnancy Body Mass Index And First Trimester Vitamin D. Arch Dis Child. 2014 Oct 1;99 (Suppl 2): A457A457.

16. Pena HR, de Lima MC, Brandt KG, de Antunes MMC, da Silva GAP. Influence of preeclampsia and gestational obesity in maternal and newborn levels of vitamin D. BMC Pregnancy Childbirth. 2015 May 13;15: 112. doi: 10.1186/s12884-015-0547-7.

17. Magnus P, Eskild A. Seasonal variation in the occurrence of pre-eclampsia. BJOG Int J ObstetGynaecol. 108(11):1116-9.https://doi.org/10.1111/j.1471-0528.

2003. 00273.x

18. Algert CS, Roberts CL, Shand AW, Morris JM, Ford JB. Seasonal variation in pregnancy hypertension is correlated with sunlight intensity. Am J Obstet Gynecol. 2010 Sep; 203 (3):215.e1-5. doi: 10.1016/j.ajog. 2010. 04.020.

\section{Original Research Article}

19. Bodnar LM, Catov JM, Simhan HN, Holick MF, Powers RW, Roberts JM. Maternal Vitamin D Deficiency Increases the Risk of Preeclampsia. J Clin Endocrinol Metab. 2007 Sep;92(9):3517-22. Epub 2007 May 29.

20. Aghajafari F, Nagulesapillai T, Ronksley PE, Tough SC, O’Beirne M, Rabi DM. Association between maternal serum 25-hydroxyvitamin D level and pregnancy and neonatal outcomes: systematic review and meta-analysis of observational studies. BMJ. 2013 Mar 26;346: f1 169. doi: https://doi.org/10.1136/bmj.f1169

21. Robinson CJ, Alanis MC, Wagner CL, Hollis BW, Johnson DD. Plasma 25-hydroxyvitamin D levels in early-onset severe preeclampsia. Am J Obstet Gynecol. 2010 Oct; 203(4): 366.e1-6. doi: 10.1016/j.ajog. 2010.06. 036. Epub 2010 Aug 8.

22. Hyppönen E, Hartikainen A-L, Sovio U, Järvelin M$\mathrm{R}$, Pouta A. Does vitamin D supplementation in infancy reduce the risk of pre-eclampsia? Eur J Clin Nutr. 2007 Sep; 61 (9):1136-9. Epub 2007 Jan 31.

23. Bakacak M, Serin S, Ercan O, Köstü B, Avci F, Kılınç M, Kiran H, Kiran G. Comparison of Vitamin D levels in cases with preeclampsia, eclampsia and healthy pregnant women. Int J Clin Exp Med. 2015 Sep 15;8(9):16280-6. E Collection 2015.

\section{How to cite this article?}

Rao A, Ghose S, Rathod S. Correlation between Serum Vitamin D levels and hypertensive disorders in pregnancy in primigravida in third trimester.Obs Rev:J obstet Gynecol 2018;4(2):21-28.doi: 10.17511/joog.2018.i02.01. 